\title{
Music Therapy as Nursing Intervention in Improving Postpartum Mothers Comfort
}

\author{
Diffa Risqa Arisdiani ${ }^{1}$, Anggorowati Anggorowati' ${ }^{1}$, Elsa Naviati ${ }^{2}$
}

${ }^{1}$ Program Magister Keperawatan, Fakultas Kedokteran, Universitas Diponegoro

2 Departemen Ilmu Keperawatan, Fakultas Kedokteran, Universitas Diponegoro

\begin{tabular}{|c|c|}
\hline Article Info & Abstract \\
\hline $\begin{array}{l}\text { Article History: } \\
\text { Submitted: Dec } 1^{\text {st }}, 2020 \\
\text { Accepted: Feb } 5^{\text {th }}, 2021 \\
\text { Published: Feb } 13^{\text {th }}, 2021 \\
\text { Keywords: } \\
\text { Music therapy; Comfort; } \\
\text { Postpartum }\end{array}$ & $\begin{array}{l}\text { Postpartum is a condition in which the reproductive organs return to normal } \\
\text { which takes } 6 \text { weeks. The feeling of discomfort in postpartum mothers } \\
\text { occurs because of the sensation of pain that is often complained of. One way } \\
\text { to increase comfort for postpartum mothers is by providing non- } \\
\text { pharmacological therapies, namely massage and listening to music. Music } \\
\text { can provide impulses or stimuli that can override the pain signals. The } \\
\text { literature review aims to describe the type of music that can increase the } \\
\text { comfort of postpartum mothers. The method used is a literature review } \\
\text { study. The database used from several journals and articles with a search } \\
\text { process through Pubmed, Proquest, Springlink, Scopus, Google Scholar. The } \\
\text { criteria for inclusion in this search were the year the articles were published, } \\
\text { starting from } 2010 \text { to } 2020 \text {. The type of classical music that has a medical } \\
\text { connection is Mozart's music. Mozart music with a frequency of } 40-60 \mathrm{~Hz} \text {, } \\
\text { tempo } 60-80 \text { bpm. Music therapy is given for approximately } 20-30 \text { minutes } \\
\text { to produce a therapeutic effect with a period of twice a day for } 2 \text { days using } \\
\text { headphones. Music used to increase comfort and reduce the anxiety that has } \\
\text { a slow tempo, notes that are not too high or too low, has a low volume and is } \\
\text { rhythmic with a simple arrangement, and a stable melody. The provision of } \\
\text { music therapy, especially Mozart adagio classical music, affects reducing } \\
\text { anxiety levels and reducing pain intensity so that it can provide a sense of } \\
\text { comfort to postpartum mothers. }\end{array}$ \\
\hline
\end{tabular}

\section{PENDAHULUAN}

Kenyamanan merupakan suatu penilaian seseorang terhadap apa yang telah dirasakan pada lingkungannya. Seseorang dapat menilai kondisi lingkungannya menggunakan rangsangan yang masuk pada dirinya melalui semua indera kemudian rangsangan tersebut dicerna langsung oleh otak untuk dinilai rasa kenyamanannya. Pemberian perhatian serta dukungan sosial dari suami memberikan dampak yang positif untuk ibu postpartum, sehingga ibu rasa kenyamanan tersebut akan muncul dan beban yang dihadapi akan berkurang [1].

Ibu postpartum akan mengalami berbagai macam permasalahan, baik masalah fisik, sosial, lingkungan dan psikososial.

Corresponding author:

Anggorowati

anggorowati@fk.undip.ac.id

Media Keperawatan Indonesia, Vol 4 No 1, February 2021

e-ISSN: 2615-1669

ISSN: 2722-2802

DOI: $\underline{10.26714 / \mathrm{mki} .4 .1 .2021 .72-82}$ 
Menyusui merupakan salah satu hal yang dapat menimbulkan stress bagi seorang ibu postpartum seringkali ibu postpartum mengalami kekhawatiran karena takut jika produksi ASI berkurang dan kurangnya pengetahuan tentang proses laktasi. Untuk mengatasi masalah tersebut diperlukan suatu stimulus yang akan mengembalikan kondisi ibu postpartum memperoleh rasa nyaman [2].

Dampak negative yang akan dialami oleh ibu postpartum apabila tidak segera diatasi akan mempengaruhi proses pemulihan ibu postpartum. Proses mobilisasi dini, bonding attachment juga akan menjadi terhambat sehingga muncul rasa ketidaknyamanan. Gangguan pola tidur juga sering dialami oleh ibu postpartum bahkan apabila muncul nyeri yang terusmenerus dapat meningkatkan risiko postpartum blues [3].

Teori mekanisme untuk meningkatkan kenyamanan pada ibu postpartum yaitu dengan cara mendengarkan musik. Serabut syaraf yang lebih kecil akan menghasilkan rangsangan dari musik tersebut yang nantinya mampu menyingkirkan signal rasa nyeri serta dapat merangsang hipofisis yang bekerja melepaskan hormon endorphin sehingga rasa nyeri pada ibu postpartum dapat berkurang [4].

Musik mempunyai beberapa kelebihan yaitu mampu memberikan ketenangan pikiran serta mempunyai manfaat sebagai pengendali emosi. Bersadarkan tempo, irama serta tinggi rendahnya nada dapat menghasikan suatu gelombang alfa dan serat dari gelombang beta yang terdapat pada pada gendang telinga, sehingga dapat memberikan rasa nyaman terhadap otak dan mampu menerima rangsangan serta memberikan efek rileks, dan dapat menidurkan [5]. Musik dapat memberikan manfaat bagi pasien karena dapat mengalihkan perhatian mereka dari pengalaman yang tidak menyenangkan. Terapi musik telah diakui sebagai intervensi medis terkait dengan manfaat klinis berbasis bukti. Dengan demikian, efek positif keseluruhan dari terapi musik Mozart dapat berfungsi sebagai stimulan yang dapat meningkatkan kinerja kognitif [6].

Kesederhanaan dari bunyi-bunyian yang dihasilkan oleh musik mozart mempunyai banyak kelebihan. Ritme, suara serta frekuensi tinggi rendahnya nada pada musik klasik mozart dapat memberikan rangsangan dan memberikan intensitas didalam otak yang sesuai dengan bentuk sel otak manusia. Bagi yang mendapatkan terapi musik, mozart mampu menciptakan rasa rileks dan ketenangn bagi yang mendengarkan [7].

Tujuan literature review ini yaitu untuk mendapatkan jenis musik yang dapat memberikan kenyamanan pada ibu postpartum.

\section{METODE}

Penulisan ini menggunakan metode studi Literatur review. Metode ini diawali dengan melakukan analisis tentang fenomena ketidaknyamanan pada ibu postpartum kemudian dilakukan sintesa terhadap pemberian pemijatan dan terapi musik. Database yang digunakan dalam penyusunan literature review menggunakan beberapa artikel yang didapatkan dari pencarian Pubmed, Proquest, Springlink, Scopus, Qoogle Scholar dengan kata kunci pencarian artikelnya menggunakan kata kenyamanan, postpartum, terapi musik dimulai dari tahun 2010 sampai 2020. Kriteria inklusi dalam pencarian sumber literatur ini diantaranya yaitu: artikel meneliti tentang pengaruh terapi musik pada ibu postpartum, artikel tersedia dalam bahasa inggris atau bahasa Indonesia, artikel tersedia full text, artikel terbit antara tahun 2010 - 2020, dan dalam bentuk research article/original article. 


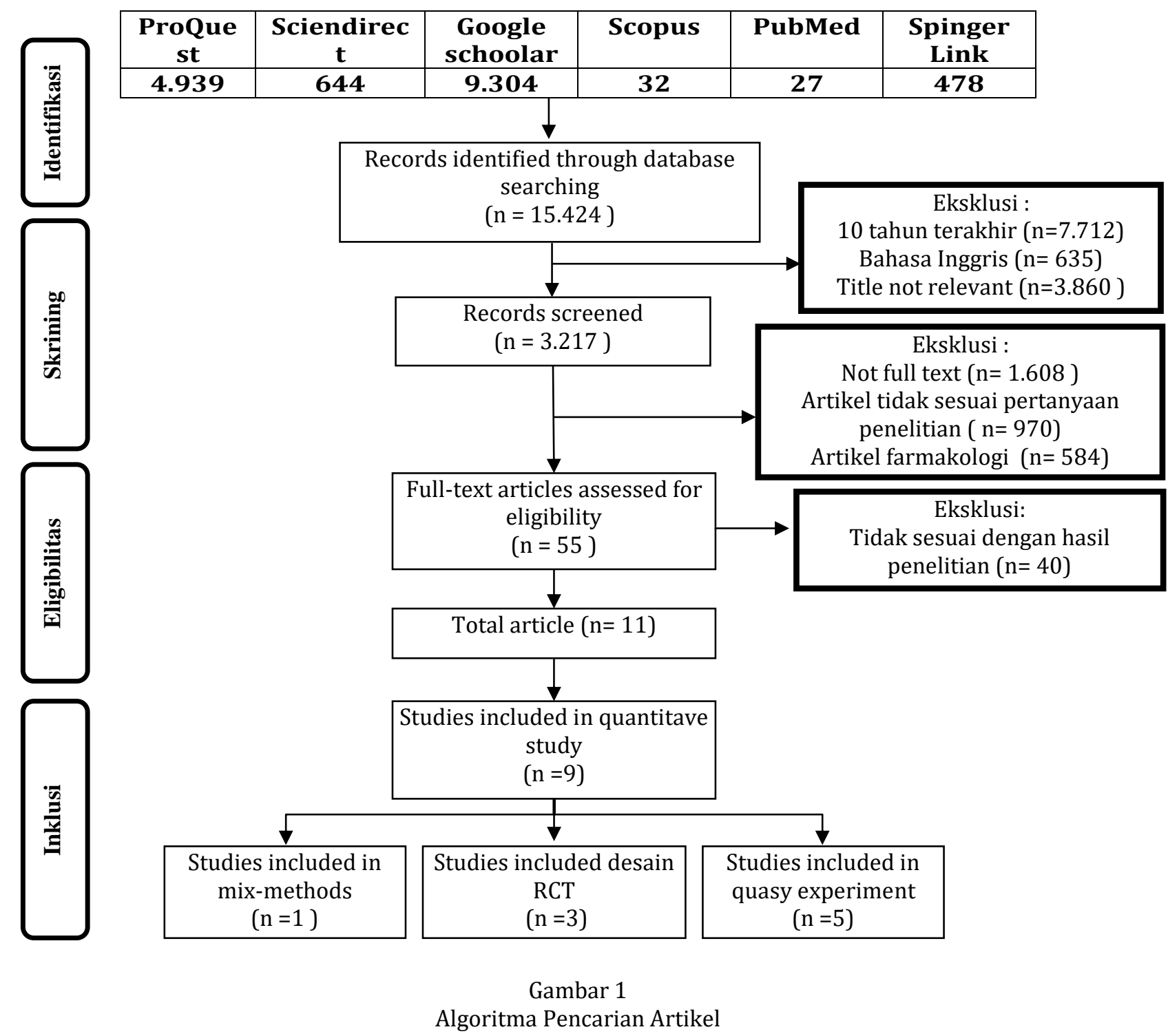

\section{HASIL}

Terapi musik bisa meningkat relaksasi dan mengurangi kecemasan, stres, dapat membantu menenangkan bayi baru lahir, saat dirawat di rumah sakit sejak masa antepartum hingga masa postpartum. Musik juga dapat mengurangi tingkat stres, memberikan dukungan emosional, dan memfasilitasi pengalaman ikatan bagi ibu dan bayi baru lahir. Durasi pemberian terapi music diberikan selama 30 menit guna mendapatkan efek terapiutik. Terapis menggunakan musik yang lembut serta diajarkan teknik manajemen stress. Terapi musik dapat diterima dengan baik dan mempunyai efek positif bagi ibu postpartum [8]. Dalam pencegahan terjadinya postpartum blues, pemberian terapi musik sangat efektif untuk diberikan. Sebagai rekomendasi intervensi pemberian terapi musik perlu diberikan pada ibu postpartum sebagai salah satu intervensi terapi relaksasi pada pelayanan kesehatan seperti di rumah sakit, puskesmas maupun klinik bersalin. Jenis terapi musik yang diberikan untuk mencegah terjadinya postpartum blues 
yaitu musik klasik Mozart: Eine Kleine Nacht dengan frekuensi 20-40 cps hertz, durasi pemberian selama 15-20 menit dan diberikan sebanyak 2 kali dalam sehari slama 3 hari berturut-turut [9].

Terapi musik klasik dapat membantu ibu postpartum dalam mengurangi tingkat nyeri dan memberikan kenyamanan pada bayi baru lahir. Terapi musik juga dapat meningkatkan efektifitas dalam pemberian ASI. Sehingga ibu yang sedang menjalani proses laktasi dapat menikmati manfaat dari terapi musik tersebut [10]. Pengaruh terapi musik klasik Mozart sangat efektif terhadap produksi ASI pada ibu postpartum. Terapi musik dapat diberikan saat dirumah sakit maupun dirumah dengan volume yang tidak terlalu keras dan tidak terlalu lemah selama 30 menit, sehingga ibu postpartum dapat menikmati alunan musik yang nantinya membuat ibu menjadi rileks dan nyaman. Musik klasik Mozart dapat membuat pikiran menjadi tenang, mengatur emosi, juga mampu membuat tempo menjadi lebih optimal, alunan nada dan harmoni stabil, sehingga dapat menciptakan gelombang alfa dan beta pada gendang telinga yang nantinya dapat memberikan ketenangan jiwa serta membuat otak dapat menerima rangsangan baru yang menjadikan tubuh menjadi lebih rileks dan dapat membuat tidur menjadi nyenyak. Getaran yang ditimbulkan dari musik mampu memberikan rangsangan pada organ pendengaran. Rangsangan tersebut di alirkan melalui system sususan syaraf pusat yang terdapat pada pusat otak. Selanjutnya di kelenjar pusat hypothalamus mempunyai rangkaian syaraf pusat yang berfungsi mengatur keterkaitan musik terhadap respon lain [5].

Rangsangan pendengaran dengan menggunakan terapi musik dapat membangkitkan emosi yang seringkali disertai dengan reaksi fisiologis seperti perubahan detak jantung, pernapasan dan sekresi hormon. Peningkatan hormon oxytocin dapat membantu ibu postpartum dalam produksi ASI. Dengan demikian, efek positif keseluruhan dari mendengarkan musik yang menyenangkan dapat berfungsi sebagai stimulan yang meningkatkan kinerja kognitif. Hal ini sangat disarankan bahwa efek musik Mozart dapat memberikan interaksi yang kompleks antara musik, gairah dan kinerja intelektual [6].

Ibu postpartum yang mendengarkan music selama periode postpartum dapat mengurangi kecemasan dan tingkat stress seseorang. Saat mendengarkan musik dengan santai dapat memberikan kenyamanan, durasi waktu yang dibutuhkan untuk memperoleh efek terapiutik yaitu sema 30 menit setiap harinya [11]. Musik dapat bekerja di sistem limbik pada sistem saraf yang mengatur kontraksi otot-otot tubuh, sehingga dapat mengurangi kontraksi otot dan kecemasan serta depresi, menurunkan frekuensi denyut jantung dan tekanan darah, serta menghilangkan nyeri. Musik mampu memberikan ketentraman pada kondisi fisik serta psikologis ibu postpartum dan dapat menciptakan lingkungan yang nyaman untuk bayinya., sehingga dapar meningkatkan ikatan batin antara ibu dan anak. Melalui tempo yang tepat musik dapat memberikan energi dan perintah sehingga dapat membantu ibu dalam mengatur pernafasan dan mengurangi tingkat nyeri yang dirasakan [12].

Berdasarkan hasil analisis pada 9 artikel yang membahas pengaruh terapi musik yang diberikan pada ibu postpartum didapatkan bahwa pemberian terapi musik pada ibu postpartum rata - rata dapat diberikan selama 30 menit setiap harinya. Pasien dapat memilih musik yang disediakan oleh therapist dengan jenis musik yang lembut, memberikan efek rileksasi, dengan ritme yang reguler atau sederhana perubahan yang ekstrem.

Hasil pemberian terapi musik pada ibu postpartum dari 9 artikel yang direview menunjukkan berbagai macam pengaruh 
atau manfaat yang dapat dirasakan oleh ibu postpartum setelah diberikan terapi musik, diantaranya yaitu meningkatkan kenyamanan, menurukan kecemasan, menumbuhkan rasa kepuasan pada ibu, mempererat hubungan ibu dengan bayi, mencegah adanya depresi atau postpartum blues, menurunkan nyeri, dan meningkatkan produksi asi pada ibu postpartum.

Tabel 1

Hasil Pencarian Artikel

\begin{tabular}{|c|c|c|c|c|c|c|}
\hline No & Author & Title & Aim & $\begin{array}{l}\text { Design of } \\
\text { study }\end{array}$ & Results & Conclusions \\
\hline 1 & $\begin{array}{l}\text { Kristen } \\
\text { Corey, MA, } \\
\text { LCAT, } \\
\text { MT-BC, } \\
\text { Ronit } \\
\text { Fallek, } \\
\text { MPA, and } \\
\text { Maya } \\
\text { Benattar } \\
(2019)\end{array}$ & $\begin{array}{l}\text { Bedsite music } \\
\text { therapy for } \\
\text { women } \\
\text { during } \\
\text { antepartum } \\
\text { and } \\
\text { postpartum } \\
\text { hospitalizatio } \\
\text { n }\end{array}$ & $\begin{array}{l}\text { Untuk menerapkan } \\
\text { intervensi terapi } \\
\text { musik di samping } \\
\text { tempat tidur dalam } \\
\text { mengurangi stress } \\
\text { dan kecemasan, } \\
\text { memberikan } \\
\text { dukungan } \\
\text { emosional, dna } \\
\text { memfasilitasi } \\
\text { ikatan ibu bayi } \\
\text { bagi perempuan } \\
\text { selama antepartum } \\
\text { hingga } \\
\text { postpartum. }\end{array}$ & $\begin{array}{l}\text { Mix- } \\
\text { methods } \\
\text { (30menit } \\
\text { selama } 7 \\
\text { hari dengan } \\
\text { music yang } \\
\text { lembut) }\end{array}$ & $\begin{array}{l}\text { Hasil penelitian } \\
\text { menunjukkan } \\
\text { terapi musik yang } \\
\text { diberikan kepada } \\
\text { ibu postpartum } \\
\text { menunjukkan } \\
\text { penerimaan yang } \\
\text { tinggi akan } \\
\text { adanya terapi } \\
\text { musik di samping } \\
\text { tempat tidur yang } \\
\text { diberikan, } \\
\text { menumbuhkan } \\
\text { kepuasan tinggi, } \\
\text { mempererat } \\
\text { koneksi dengan } \\
\text { bayinya, }\end{array}$ & $\begin{array}{l}\text { Terapi musik } \\
\text { dapat } \\
\text { meningkatkan } \\
\text { relaksasi dan } \\
\text { mengurangi } \\
\text { kecemasan serta } \\
\text { stress di antara } \\
\text { ibu postpartum } \\
\text { dalam membantu } \\
\text { menenangkan } \\
\text { bayi baru lahir } \\
\text { dan memfasilitasi } \\
\text { ikatan ibu dan } \\
\text { bayi }\end{array}$ \\
\hline 2 & $\begin{array}{l}\text { Suryani } \\
\text { (2011) }\end{array}$ & $\begin{array}{l}\text { Efektivitas } \\
\text { Terapi Musik } \\
\text { Terhadap } \\
\text { Pencegahan } \\
\text { Postpartum } \\
\text { Blues Pada } \\
\text { Ibu Primipara }\end{array}$ & $\begin{array}{l}\text { mengetahui } \\
\text { efektifitas terapi } \\
\text { musik dalam } \\
\text { mencegah } \\
\text { postpartum blues } \\
\text { pada ibu } \\
\text { postpartum } \\
\text { primipara }\end{array}$ & $\begin{array}{l}\text { Quasi } \\
\text { Experiment } \\
\text { pretest- } \\
\text { postest } \\
\text { dengan } \\
\text { kelompok } \\
\text { kontrol dan } \\
\text { kelompok } \\
\text { intervensi. }\end{array}$ & $\begin{array}{l}\text { Terapi musik } \\
\text { efektif pada } \\
\text { kelompok } \\
\text { intervensi diberi } \\
\text { terapi musik } \\
\text { instrumental } \\
\text { yakni musik } \\
\text { klasik tipe } \\
\text { Mozart: Eine } \\
\text { Kleine } \\
\text { Nachtmusik } \\
\text { dengan frekuensi } \\
20-40 \text { cps hertz } \\
\text { lamanya } 15-20 \\
\text { menit, dilakukan } \\
2 \text { kali sehari yakni } \\
\text { pukul } 8.00 \text { dan } \\
\text { pukul } 14.00 \\
\text { selama } 3 \text { hari }\end{array}$ & $\begin{array}{l}\text { pemberian terapi } \\
\text { music klasik tipe } \\
\text { Mozart sangat } \\
\text { efektif dalam } \\
\text { pencegahan } \\
\text { postpartumm } \\
\text { blues. }\end{array}$ \\
\hline 3 & $\begin{array}{l}\text { Jiemin } \\
\text { Zhu,MSc,R } \\
\text { N(Assista } \\
\text { ntProfesso } \\
\text { r)a, Hong- } \\
\text { GuHe,PhD, } \\
\text { RN,MD } \\
\text { (Assistant } \\
\text { Professor) } \\
\text { b, } \\
\text { XiuzhuZho } \\
\text { u,BSc, } \\
\text { (2015) }\end{array}$ & $\begin{array}{l}\text { Pain relief } \\
\text { effect of } \\
\text { breast feeding } \\
\text { and music } \\
\text { therapy } \\
\text { during heel } \\
\text { lance for } \\
\text { healthy-term } \\
\text { neonates in } \\
\text { China: A } \\
\text { randomized } \\
\text { controlled } \\
\text { trial }\end{array}$ & $\begin{array}{l}\text { Menguji kombinasi } \\
\text { pemberian ASI dan } \\
\text { terapi music untuk } \\
\text { menghilangkan } \\
\text { rasa sakit / nyeri } \\
\text { pada proses } \\
\text { menyusui pada ibu } \\
\text { postpartum. }\end{array}$ & RCT & $\begin{array}{l}\text { Menunjukkan } \\
\text { bahwa terapi } \\
\text { music tidak } \\
\text { terlalu } \\
\text { berpengaruh } \\
\text { dalam } \\
\text { menghilangkan } \\
\text { nyeri saat } \\
\text { menyusui. }\end{array}$ & $\begin{array}{l}\text { Menyusui telah } \\
\text { dievalusi secara } \\
\text { eksklusif untuk } \\
\text { efektivitasnya } \\
\text { pada nyeri. Selain } \\
\text { itu, interaksi, } \\
\text { sentuhan ibu } \\
\text { kepada bayi saat } \\
\text { menyusui dapat } \\
\text { membantu } \\
\text { mengurangi } \\
\text { nyeri }\end{array}$ \\
\hline
\end{tabular}




\begin{tabular}{|c|c|c|c|c|c|c|}
\hline No & Author & Title & Aim & $\begin{array}{c}\text { Design of } \\
\text { study }\end{array}$ & Results & Conclusions \\
\hline 4 & $\begin{array}{l}\text { Ratna } \\
\text { Dewi } \\
(2016)\end{array}$ & $\begin{array}{l}\text { Efektifitas } \\
\text { Pemberian } \\
\text { Terapi Musik } \\
\text { Klasik } \\
\text { (Mozart) } \\
\text { terhadap } \\
\text { Produksi Asi }\end{array}$ & $\begin{array}{l}\text { mengetahui } \\
\text { efektifitas } \\
\text { pemberian terapi } \\
\text { musik klasik } \\
\text { (mozart) terhadap } \\
\text { produksi ASI }\end{array}$ & $\begin{array}{l}\text { Quasi } \\
\text { Experiment }\end{array}$ & $\begin{array}{l}\text { Ada pengaruh } \\
\text { terapi musik } \\
\text { klasik (mozart) } \\
\text { terhadap } \\
\text { produksi ASI, } \\
\text { tidak ada } \\
\text { hubungan paritas } \\
\text { dan dukungan } \\
\text { tenaga kesehatan } \\
\text { dengan produksi } \\
\text { ASI, dan ada } \\
\text { hubungan } \\
\text { dukungan suami } \\
\text { dan keluarga } \\
\text { dengan produksi } \\
\text { ASI. }\end{array}$ & $\begin{array}{l}\text { Terapi music } \\
\text { music Mozart } \\
\text { berpengaruh } \\
\text { terhadap } \\
\text { produksi ASI }\end{array}$ \\
\hline 5 & $\begin{array}{l}\text { Simavli S, } \\
\text { Kaygusuz } \\
\text { I, Gumus I, } \\
\text { Usluogulla } \\
\text { r1 B, } \\
\text { Yildirim } \\
\text { M, Kafali } \\
\text { H (2014) }\end{array}$ & $\begin{array}{l}\text { Does music } \\
\text { during } \\
\text { delivery help } \\
\text { to decrease } \\
\text { postpartum } \\
\text { blues? }\end{array}$ & $\begin{array}{l}\text { Untuk } \\
\text { mengevaluasi } \\
\text { penerapan terapi } \\
\text { music pada ibu } \\
\text { postpartum dalam } \\
\text { mengatais nyeri, } \\
\text { tingkat kecemasan } \\
\text { dan kepuasan serta } \\
\text { gejala depresi dini } \\
\text { selama masa pasca } \\
\text { persalinan. }\end{array}$ & RCT & $\begin{array}{l}\text { Menunjukkan } \\
\text { bahwa terapi } \\
\text { music yang } \\
\text { diberikan yaitu } \\
\text { music klasik, } \\
\text { music ringan, } \\
\text { music popular, } \\
\text { music seni Turki } \\
\text { dan music sufi } \\
\text { Turki secara } \\
\text { signifikan } \\
\text { berpengaruh } \\
\text { terhadap } \\
\text { penuruna } \\
\text { kecmasan dan } \\
\text { ketidkanyamanan } \\
\text { ibu postpartum } \\
\text { pasca persalinan. }\end{array}$ & $\begin{array}{l}\text { Terapi music } \\
\text { dapat } \\
\text { direkomendasika } \\
\text { n secara klinis } \\
\text { sebagai } \\
\text { intervensi non } \\
\text { farmakologis } \\
\text { alternative, } \\
\text { aman, mudah } \\
\text { dan } \\
\text { menyenangkan } \\
\text { untuk } \\
\text { meningkatkan } \\
\text { kesehatan dna } \\
\text { kenyamanan } \\
\text { dalam adaptasi } \\
\text { postpartum. } \\
\text { Namun, hasil } \\
\text { penelitian ini } \\
\text { mungkin relevan } \\
\text { hanya untuk ibu } \\
\text { postpartum yang } \\
\text { tidak dengan } \\
\text { kehamilan } \\
\text { komplikasi. }\end{array}$ \\
\hline 6 & $\begin{array}{l}\text { Ernest K.J. } \\
\text { Pauwels, } \\
\text { Duccio } \\
\text { Volterrani } \\
\text { Giuliano } \\
\text { Mariani } \\
\text { Magdalen } \\
\text { a } \\
\text { Kostkiewi } \\
\text { c } \\
(2014)\end{array}$ & $\begin{array}{l}\text { Mozart, Music } \\
\text { and Medicine }\end{array}$ & $\begin{array}{l}\text { Untuk membantu } \\
\text { mengurangi beban } \\
\text { penyakit dan } \\
\text { meningkatkan } \\
\text { sistem kekebalan }\end{array}$ & RCT & $\begin{array}{l}\text { Menunjukkan } \\
\text { bahwa } \\
\text { mendengarkan } \\
\text { musik dapat } \\
\text { mengaktifkan } \\
\text { area serebral } \\
\text { kortikal dan } \\
\text { subkortikal serta } \\
\text { menunjukkan } \\
\text { bahwa } \\
\text { rangsangan } \\
\text { pendengaran } \\
\text { dapat } \\
\text { membangkitkan } \\
\text { perasaan } \\
\text { seseorang }\end{array}$ & $\begin{array}{l}\text { Terapi music } \\
\text { dengan } \\
\text { mendengarkan } \\
\text { musik yang } \\
\text { disukai } \\
\text { dapat } \\
\text { membangkitkan } \\
\text { emosi dan } \\
\text { meningkatkan } \\
\text { gairah serta } \\
\text { menghasilkan } \\
\text { kinerja yang } \\
\text { kognitif. }\end{array}$ \\
\hline 7 & $\begin{array}{l}\text { Ying-Fen } \\
\text { Tseng, }\end{array}$ & $\begin{array}{l}\text { Effects of } \\
\text { listening to }\end{array}$ & $\begin{array}{l}\text { Untuk menyelidiki } \\
\text { efek }\end{array}$ & RCT & $\begin{array}{l}\text { Hasil penelitian } \\
\text { menunjukkan }\end{array}$ & $\begin{array}{l}\text { Menggunakan } \\
\text { music untuk }\end{array}$ \\
\hline
\end{tabular}




\begin{tabular}{|c|c|c|c|c|c|c|}
\hline No & Author & Title & Aim & $\begin{array}{c}\text { Design of } \\
\text { study }\end{array}$ & Results & Conclusions \\
\hline & $\begin{array}{l}\text { Chung- } \\
\text { Hey Chen } \\
\text { and } \\
\text { ChihChen } \\
\text { S Lee } \\
(2010)\end{array}$ & $\begin{array}{l}\text { music on } \\
\text { postpartum } \\
\text { stress and } \\
\text { anxiety levels }\end{array}$ & $\begin{array}{l}\text { mendengarkan } \\
\text { musik yang dipilih } \\
\text { secara khusus dan } \\
\text { menangkan rumah, } \\
\text { untuk menurunkan } \\
\text { stress, kecemasan } \\
\text { pada ibu } \\
\text { postpartum pasca } \\
\text { persalinan. }\end{array}$ & & $\begin{array}{l}\text { bahwa ibu nifas } \\
\text { yang menyimak } \\
\text { music dalam } \\
\text { proses } \\
\text { memperoleh } \\
\text { kenyamanan } \\
\text { selama dua } \\
\text { minggu tidak } \\
\text { menampilkan } \\
\text { perbedaan yang } \\
\text { signifikan dan } \\
\text { skor perbedaan, } \\
\text { namun intervensi } \\
\text { terapi ini dapat } \\
\text { dilakukan oleh } \\
\text { semua ibu pasca } \\
\text { melahirkan. }\end{array}$ & $\begin{array}{l}\text { mengatasi } \\
\text { masalah } \\
\text { psikologis dan } \\
\text { fisiologis mampu } \\
\text { untuk } \\
\text { meningkatkan } \\
\text { kesehatan dan } \\
\text { partisipasi aktif } \\
\text { dari diri pasien } \\
\text { karena } \\
\text { mendengarkan } \\
\text { music sudah } \\
\text { terjalin dengan } \\
\text { baik sejak dalam } \\
\text { proses kehamilan } \\
\text { hingga } \\
\text { postpartum }\end{array}$ \\
\hline 8 & $\begin{array}{l}\text { Serap } \\
\text { Simavli a, } \\
\text { c Ilknur } \\
\text { Gumus b } \\
\text { Ikbal } \\
\text { Kaygusuz } \\
\text { b Melahat } \\
\text { Yildirim b } \\
\text { Betul } \\
\text { Usluogulla } \\
\text { ri b Hasan } \\
\text { Kafali } \\
\text { (2013) }\end{array}$ & $\begin{array}{l}\text { Effect of } \\
\text { Music on } \\
\text { Labor Pain } \\
\text { Relief, Anxiety } \\
\text { Level and } \\
\text { Postpartum } \\
\text { Analgesic } \\
\text { Requirement: } \\
\text { A } \\
\text { Randomized } \\
\text { Controlled } \\
\text { Clinical Trial }\end{array}$ & $\begin{array}{l}\text { Untuk } \\
\text { mengevaluasi efek } \\
\text { pemberian music } \\
\text { sejak nyeri } \\
\text { persalinan dan } \\
\text { kecemasan, } \\
\text { hemodinamik, } \\
\text { serta bersifat } \\
\text { analgesic pada ibu } \\
\text { postpartum } \\
\text { primipara }\end{array}$ & RCT & $\begin{array}{l}\text { Hasil penelitian } \\
\text { menunjukkan } \\
\text { efek yang } \\
\text { bermanfaat pada } \\
\text { kecemasan dan } \\
\text { rasa sakit ibu } \\
\text { selama proses } \\
\text { persalinan pada } \\
\text { hemodinamiknya } \\
\text { dan kenyamanan } \\
\text { pada proses } \\
\text { postpartum dalam } \\
\text { proses interaksi } \\
\text { ibu-bayi. }\end{array}$ & $\begin{array}{l}\text { Mendengarkan } \\
\text { music } \\
\text { berdampak } \\
\text { positif selama } \\
\text { proses } \\
\text { persalinan } \\
\text { hingga } \\
\text { postpartum } \\
\text { untuk mengatasi } \\
\text { nyeri dan } \\
\text { kecemasan. }\end{array}$ \\
\hline 9 & $\begin{array}{l}\text { Rodiana } \\
(2016)\end{array}$ & $\begin{array}{l}\text { Pengaruh } \\
\text { Pemberian } \\
\text { Terapi Musik } \\
\text { Klasik dalam } \\
\text { Menurunkan } \\
\text { Tingkat } \\
\text { Kecemasan } \\
\text { Ibu Hamil } \\
\text { Menjelang } \\
\text { Persalinan }\end{array}$ & $\begin{array}{l}\text { Menjelaskan } \\
\text { tentang terapi } \\
\text { music klasik dalam } \\
\text { menurunkan } \\
\text { tingkat kecemasan } \\
\text { pada ibu bersalin }\end{array}$ & $\begin{array}{l}\text { Quasi } \\
\text { experiment }\end{array}$ & $\begin{array}{l}\text { Adanya pengarug } \\
\text { dalam pemberian } \\
\text { intervensi terapi } \\
\text { music Mozart } \\
\text { dalam penurunan } \\
\text { tingkat } \\
\text { kecemasan dan } \\
\text { penurunan } \\
\text { intensitas nyeri } \\
\text { pada ibu saat } \\
\text { menjalani proses } \\
\text { persalinan. }\end{array}$ & $\begin{array}{l}\text { Musik Mozart } \\
\text { berpengaruh } \\
\text { dalam } \\
\text { menurunkan } \\
\text { tingkat } \\
\text { kecemasan dan } \\
\text { intensitas nyeri } \\
\text { saat persalinan }\end{array}$ \\
\hline
\end{tabular}

Analisa sintesa dari literature review di jelaskan pada bagan dibawah ini :

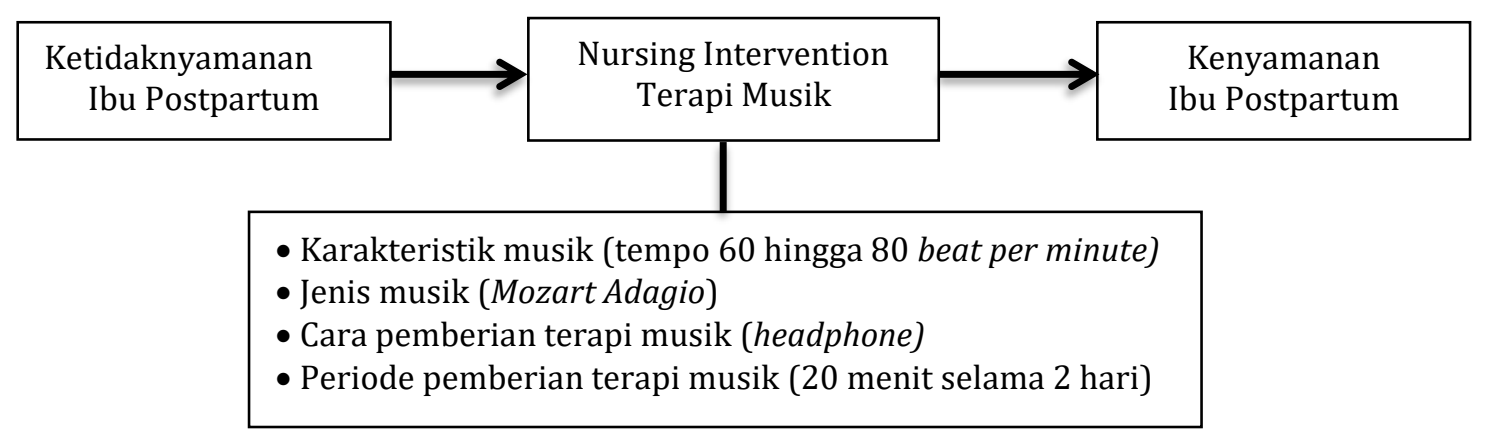

Gambar 2

Analisa sintesis kenyamanan ibu postpartum 


\section{PEMBAHASAN}

Berdasarkah hasil review dari 9 artikel didapatkan pemberian terapi musik selama 30 menit setiap harinya pada ibu postpartum menunjukkan berbagai efek yang positif. Terapi musik merupakan cara untuk menciptakan lingkungan yang menenangkan serta dapat meningkatkan kesejahteraan pasien yang sedang menjalani proses perawatan. Musik dapat mengurangi kecemasan dan memberikan rasa nyaman pada ibu postpartum, menstabilkan tanda-tanda vital, meningkatkan bonding, menenangkan bayi sehingga dapat mempersingkat durasi rawat inap di rumah sakit. Penurunan tingkat nyeri didapatkan pada ibu postpartum yang telah mendapatkan intervensi terapi musik. Sebaliknya pada kelompok kontrol terdapat perbedaan yang signifikan dalam hal hemodinamik ibu setelah diberikan intervensi $(p<0.01)$ [13].

Transisi menjadi seorang ibu dapat menjadi tantangan bagi seorang perempuan. Pengalaman ibu postpartum biasanya timbul tantangan signifikan. Tantangan menjadi seorang ibu terletak pada tindakan persalinan itu sendiri yang dapat menjadi sumber stres, kecemasan, dan rasa sakit. Banyak masalah yang sering muncul pada ibu postpartum seperti kecemasan, rasa sakit lateralis luka atau laserasi perineum, pembengkakan payudara, perubahan suasana hati, serta depresi postpartum [14]. Suryani (2011) menjelaskan bahwa terjadi penurunan skor kejadian postpartum blues pada ibu yang diberikan intervensi terapi musik sebesar 1,80. Sedangkan pada Ibu yang tidak mendapatkan terapi musik memiliki peluang untuk mengalami postpartum blues sebesar 5,60 kali dibanding dengan ibu yang diberi terapi music [9].

Mendengarkan musik merupakan teknik distraksi yang dapat memberikan rangsangan serta mampu mengalihkan fokus perhatian yang lain. Terapi musik termasuk dalam terapi nonfarmakologi dengan pendekatan noninvasive, sehingga risikonya lebih rendah rendah, biayanya cukup terjangkau, mudah didapatkan serta berada di lingkungan keperawatan. Pemberian musik dapat menciptakan rasa nyaman, meningkatkan mobilitas, dapat mengubah respon pikiran, menurunkan rasa cemas, dan dapat memberi kekuatan sebagai pengontrol rasa sakit yang dialami [15].

Berdasarkan review dari 9 artikel yang membahas pemberian terapi musik pada ibu pot partum, musik yang digunakan untuk menambah kenyamanan dan mengurangi kecemasan adalah musik dengan ritme lambat, nada tidak terlalu tinggi atau terlalu rendah, volume rendah, ritme sederhana, dan ritme sederhana. Musik yang menenangkan dapat menurunkan tingkat katekolamin, sehingga menurunkan detak jantung dan tekanan darah. Merilekskan tubuh dan pikiran dengan mendengarkan musik dapat mengurangi kecemasan, kondisi fisik dan jiwa menjadi stabil, serta dapat terciptanya lingkungan yang nyaman [16].

Karakteristik musik yang mempunyai sifat sebagai terapi dapat menggunakan musik yang tanpa dramatis, mempunyai dinamika yang dapat diprediksi, dengan irama nada yang lembut, harmonis, serta tanpa menggunakan lirik, dan mempunyai tempo 60 hingga 80 beat per minute. Sebaliknya musik yang tidak mempunyai sifat sebagai terapi dapat menimbulkan ketegangan, yaitu musik yang mempunyai tempo cepat, irama yang keras, ritme yang tidak teratur, tidak hamonis, serta mempunyai volume keras sehingga musik tersebut tidak dapat mempunyai efek sebagai terapi. Efek dari mendengarkan musik yang keras dapat mempengaruhi kenaikan denyut jantung, peningkatan tekanan darah, frekuensi pernafasan yang cepat serta ketegangan menjadi lebih meningkatkan [17].

Musik yang diberikan biasanya memiliki tempo 40-80 detak per menit yang tergolong jenis musik slow speed dan 
medium speed. Pilihan musik lebih bersifat klasik dan internasional, seperti Mozart dan Beethoven [18]. Virgianti (2016) menjelaskan bahwa kondisi fisik dan psikologis seseorang dapat dipengaruhi oleh musik yang mempunyai irama lembut dan teratur. Frekuensi yang menghasilkan getaran serta harmoni musik yang digunakan sesuai maka akan mendapatkan rasa nyaman pada si pendengar, sehingga kenyamanan tersebut akan membuat seseorang menjadi tenang serta menjadikan seseorang lebih rileks.

Musik klasik Mozart merupakan jenis musik yang nyaman didengarkan serta dapat dijadikan sebagai terapi musik dalam dunia medis. Berdasarkan perkembangan ilmu kesehatan musik Mozart memiliki perbandingan yang luar biasa dibamndingkan dengan musik yang lainnya, Mozart mempunyai irama yang lembut, nadanya memberikan stimulasi gelombang alfa, ketenangan, dan membuat pendengaran lebih rileks [19]. Penelitian lain menunjukkan bahwa musik telah terbukti dapat mempengaruhi fisiologi, emosi, memori, tugas, mengurangi depresi dan rasa sakit, dan meningkatkan motivasi. Musik mampu mempengaruhi keadaan mood individu. Penelitian juga menunjukkan pengaruh positif dalam proses penyembuhan Kesehatan [20].

Musik klasik Mozart mempunyai nada lembut sehingga dapat merangsang gelombang alfa, dapat menciptakan kenyamanan, rasa tenang serta dapat mengalihakan perhatian sehingga dapat menghilangkan rasa sakit [12]. Musik klasik Mozart diyakini berdampak positif bagi kehidupan manusia karena lagunya. Musik klasik Mozart menghibur, mendukung pembelajaran, dan kaya. Karena musik klasik yang bertempo lambat memengaruhi ritme jantung, maka akan menghasilkan suara yang tenang, dan suara yang didengar melalui telinga dapat diterima melalui otak yang kemudian akan langsung diproses yang nantinya akan berdampak baik bagi kesehatan. Hasil penelitian lain menunjukkan bahwa terapi musik klasik Mozart dapat secara efektif mengurangi intensitas nyeri. Fakta membuktikan bahwa setelah mendapat terapi musik klasik Mozart, intensitas nyeri ibu postpartum mengalami penurunan. Penelitian ini didukung oleh penelitian yang menyatakan bahwa musik klasik Mozart adalah musik slow, atau sesuai dengan ritme jantung meresponnya dengan mengeluarkan hormon serotonin yang membuat perasaan senang dan bahagia [19].

Otak berperan dalam mengubah kondisi fisik tubuh sebagai respons terhadap musik. Alunan musik mampu membantu tubuh menjadi rileks, sehingga dapat menciptakan suasana yang tenang. Selain itu irama jantung juga dapat merespon musik yang sedang didengarkan. Pengaruh musik terhadap emosi akan lebih mempengaruhi psikologi manusia dan dapat membuat tubuh bergerak lebih jauh setelah melahirkan [21]. Musik telah dikenal untuk mengaktifkan otak yang terlibat dalam mengatur emosi dan dapat memicu respon menyenangkan [22]. Penggunaan headphone dalam terapi musik lebih di anjurkan dengan alasan headphone lebih bersifat personal yaitu hanya responden saja yang dapat mendengarkan musiknya, Sehingga responden lebih fokus dan dapat menikmati musiknya selain itu bantalan headphone mudah diganti guna mencegah terjadinya penularan bakteri yang terdapat dari telinga responden satu ke responden yang lainnya serta lebih safety [23].

Musik mempunyai sifat terapeutik yang berarti dapat menyembuhkan. Musik mampu menciptakan rangsanganrangsangan yang nantinya akan ditangkap oleh organ pendengaran kemudian diproses didalam system syaraf dan kelenjar otak selanjutnya di interpretasikan oleh organ pendengaran. Terapi musik agar mendapatkan efek terapeutik harus didengarkan minimal 15 menit karena sangat efektif sebagai upaya 
untuk mengurangi nyeri [16]. Hasil penelitian telah mengevaluasi keefektifan musik dalam mengatasi stress dan nyeri yang berhubungan dengan media. Beberapa penelitian sebelumnya telah menemukan music efektif dalam mengurangi nyeri dan kecemasan yang berhubungan dengan pembedahan dan kanker.[20] Pemberian terapi musik yang mampu menurunkan tingkat nyeri pada pasien post operasi dan menurunkan tingkat kecemasan [24,25].

\section{SIMPULAN}

Teknik distraksi dengan terapi musik Mozart Adagio yang mempunyai tempo lambat, tinggi rendahnya nada yang seimbang, mempunyai tingkat suara yang rendah dan berirama. Arrangement dalam musik Mozart adagio yang sederhana, serta melodi yang stabil mampu membantu ibu postpartum dalam proses pelepasan hormone endorfin yang ada di dalam tubuh sehingga mampu menghambat transmisi nyeri. Pemberian terapi musik terutama musik klasik Mozart Adagio mempunyai pengaruh dalam menurunkan tingkat kecemasan dan menurunkan intensitas nyeri sehingga dapat memberikan rasa nyaman pada ibu postpartum.

\section{UCAPAN TERIMAKASIH}

Kepada segenap pihak yang telah mendukung dalam upaya penyusunan studi literature ini kami ucapkan terimakasih atas perhatian dan dukungannya.

\section{REFERENSI}

[1] Rahayu D. Peningkatan kenyamanan ibu postpartum dengan pijat oksitosin pendekatan teory comfort colcaba 2020;10:319-26.

[2] Rahayuningsih T, Mudigdo A, Murti B. Effect of Breast Care and Oxytocin Massage on Breast Milk Production: A study in Sukoharjo Provincial Hospital. J Matern Child Heal 2016;01:101-9. https://doi.org/10.26911/thejmch.2016.01
.02 .05 .

[3] Vasra E, Sukarni D. Pengaruh terapi non invasif pada ibu postpartum berdasarkan evidance base terhadap intensitas nyeri di BPM kota Palembang 2018;12:117-23.

[4] Zamanifar S, Bagheri-Saveh MI, Nezakati A, Mohammadi R, Seidi J. The Effect of Music Therapy and Aromatherapy with Chamomile-Lavender Essential Oil on the Anxiety of Clinical Nurses: A Randomized and Double-Blind Clinical Trial. J Med Life 2020;13:87-93.

https://doi.org/10.25122/jml-2019-0105.

[5] Almuslim JK, Politeknik D, Kementerian K, Bengkulu K, Kebidanan J. Efektifitas Pemberian Terapi Musik Klasik (Mozart) Terhadap Produksi Air Susu Ibu (ASI). Kes Mas J Fak Kesehat Masy 2016;10:78-85. https://doi.org/10.12928/kesmas.v10i2.46 35.

[6] Pauwels EKJ, Volterrani D, Mariani G, Kostkiewics M. Mozart, music and medicine. Med Princ Pract 2014;23:403-12. https://doi.org/10.1159/000364873.

[7] Oliver J. Music Mozart. Hilos Tensados 2019;1:1-476.

https://doi.org/10.1017/CB09781107415 324.004.

[8] Corey K, Fallek R, Benattar M. Bedside Music Therapy for Women. Am J Matern Child Nurs 2019;44:277-83.

https://doi.org/10.1097/NMC.000000000 0000557.

[9] Manurung S, Lestari TR, Suryati B, Miradwiyana B, Karma A. Effectiveness of music therapy on prevention of postpartum blues in primipara mothers in the midwifery moom of cipto mangunkusumo general hospital, central Jakarta. Bull Heal Syst Res 2011;14:17-23.

[10] Zhu J, Hong-Gu H, Zhou X, Wei H, Gao Y, Ye B, et al. Pain relief effect of breast feeding and music therapy during heel lance for healthyterm neonates in China: A randomized controlled trial. Midwifery 2015;31:365-72. https://doi.org/10.1016/j.midw.2014.11.0 01.

[11] Tseng Y, Chen C, Lee CS. Effects of listening to music on postpartum stress and anxiety levels. J Clin Nurs 2010;19:1049-55.

[12] Moekroni R, Analia. Pengaruh Pemberian Terapi Musik Klasik dalam Menurunkan Tingkat Kecemasan Ibu Hamil Menjelang Persalinan. Majority 2016;5:6-11.

[13] Simavli S, Gumus I, Kaygusuz I, Yildirim M, Usluogullari B, Kafali H. Effect of music on 
labor pain relief, anxiety level and postpartum analgesic requirement: A randomized controlled clinical trial. Gynecol Obstet Invest 2014;78:244-50. https://doi.org/10.1159/000365085.

[14] Du C. An Exploration of Music Therapists ' Perspectives on Preventing and Treating Postpartum Depression 2016.

[15] Potter Dan Perry. Buku Ajar Fundamental Keperawatan: Konsep, Proses dan Praktik. 2nd ed. Jakarta: EGC; 2006.

[16] Ratnawati AE, Julianti HP, Program M, Program P, Epidemiologi S, Sain K, et al. Perbedaan musik klasik mozart dan instrumental modern kitaro terhadap tingkat kecemasan ibu hamil primigravida 2014;5.

[17] Erwin. Pengaruh terapi musik tradisional terhadap respon nyeri pada pasien paska operasi 2019;13:163-71.

[18] Amelia D, Trisyani M. Terapi musik terhadap penurunan tingkat depresi. 'Afiyah 2015;2.

[19] Program M, Ilmu S, Fakultas K, Kesehatan I, Tribhuwana U, Malang T, et al. Nursing News Volume 2, Nomor 3, 2017 2017;2:44-57.

[20] Vanessa A. Flores MA. Effects of Positive Music in Psychotherapy 2011.
[21] Magister P, Politeknik K, Padang K, Onkologi B, Faal D. Perbandingan Efek Musik Klasik Mozart dan Musik Tradisional Gamelan Jawa terhadap Pengurangan Nyeri Persalinan Kala I Fase Aktif pada Nulipara Comparison of Classical Music Mozart Efect and Javanese Gamelan Music Efect to Relief Labor Pain in Stage I Acti 2011;45.

[22] Yager AM, Kozlowski JL, Committee C. Does Music Therapy Improve Depressive Symptoms in the Mothers of Chronically Ill Children? A Clinical Scholarly Project by Marybelle and S. Paul Musco School of Nursing and Health Professions Irvine, California Submitted in partial fulfillment of the $r 2019$.

[23] Good MA. A comparison of music therapy and jaw relaxation on postoperative pain. 1995.

[24] Barus NS, Siregar D. Kajian Literatur: Efektivitas Terapi Musik Klasik Terhadap Halusinasi Pendengaran Pada Pasien Skizofrenia. J Nurs Curr 2019;7:48-57.

[25] Aprillia. Pengaruh Waktu Pemberian Terapi Musuik terhadap Penurunan Tingkat Kecemasan pada Pasien Pre Operasi Sectio Caesaria 2018. 